\title{
EFFECT OF CERTAIN MOUTHWASHES ON THE NUMBER OF ORAL BACTERIA ${ }^{1}$
}

MARY C. CROWLEY, M.S., AND U. GARFIELD RICKERT, D.D.S., F.A.C.D.

School of Dentistry, University of Michigan, Ann Arbor, Mick.

The purpose of this study was to determine the duration of the inhibitory effect of some of the popular mouthwashes on the oral bacteria. All of the preparations used with the exception of one, Azochloramid, were bought in the open market. Azochloramid is a new preparation and was supplied to us by the manufacturer.

Two experiments were carried out. In the first, Pepsodent, Lavoris, and Hexylresorcinol were diluted 1:1 with water, while Azochloramid was made up by dissolving one tablet in $50 \mathrm{cc}$. of water. This dilution of the first four products named was used because all of the manufacturers of these products advertise that dilutions of that strength can be used, as well as weaker dilutions. Since these were preliminary tests, we used the greater concentration which should be the most efficacious. Tests were made on six individuals, but not all mouthwashes were used on all individuals.

In the second experiment, Azochloramid- 1 tablet in $50 \mathrm{cc}$. of water, Chlorozene-1 tablet dissolved in $125 \mathrm{cc}$. water, Zonite-1:10 dilution and Pepsodent-1:3 dilution were used. Tests were made on two individuals, one of whom (M. C.) had been tested in Experiment I.

The methods of sampling were identical in both experiments and were the same as reported in a previous publication. ${ }^{2}$ Briefly, samples were collected by brushing the teeth and then rinsing both mouth and toothbrush with $\mathrm{N} / 300 \mathrm{NaOH}$. This material was sprayed through an atomizer especially devised to break up the larger clumps. The volume of the sprayed material was made up to $20 \mathrm{cc}$. with N/300 $\mathrm{NaOH}$ and 0.01 cc. portions smeared out on a glass slide, stained by

1 Read at the 15th Annual Meeting of the International Association for Dental Research at Baltimore, Maryland, March 14, 1937.

This work was carried on, in part, by grants from Wallace and Tiernan Company.

2 Crowley, M. C. and Rickert, U. G., J. Bact. 30:4, 1935. 
Gram's method, and counted. In this study, $\mathrm{N} / 300 \mathrm{NaOH}$ was substituted for $\mathrm{N} / 400 \mathrm{NaOH}$ as reported in the previous publication. Food was restricted to fluids during an eight hour period on test days. The initial sample was collected two hours after breakfast. Immediately after the first sample was collected, $15 \mathrm{cc}$. of the preparation to be tested was swished thoroughly in the mouth for 1 minute. Counts were then made at 3 and 6 hour intervals after the use of the mouthwash. The same procedure was carried out on days in which control counts were made with the exception that no mouthwash was used. Control counts were made in order to determine the normal count fluctuations in the individual. Counts for controls and mouthwashes were made at the same time of day on different days. At least 1 day intervened between counts. In these cases neither caries nor gingivitis were clinically demonstrable. In order that the normal oscillation of counts would not confuse their interpretation, only averages of at least 3 were considered, except Listerine and Hexylresorcinol in M. K. (See Table I.) This means that at least 72 counts were made for each mouthwash tested and for each control.

In the past it has been customary to compare the counts obtained after the use of the materials tested with the initial count which was made before the use of the mouthwash. The initial counts, however, were found to be unsatisfactory controls because of their normal fluctuation. We, therefore, in this study compared the average of counts taken on treatment days, with the average of counts made on control days. The accompanying tables are constructed on the basis of percentage variation from the initial count on treatment and control days.

These tables show the number of counts made on each mouthwash, averages of the counts made before the use of the mouthwash, three hours and six hours after the use of the mouthwash, with the decrease or increase from the initial account expressed in per cent.

Experiment I-Table I. In the case of M. C., Pepsodent in a 1:1 dilution showed the greatest decrease, a difference of about 40 per cent from the control count. Azochloramid showed a good reduction. In the case of M. K., Azochloramid and Pepsodent were good. With F. H., Lavoris showed a big decrease at 3 hours but not much at 6 hrs. 
Pepsodent 1:1 was good. Listerine showed an increase after being used. The remainder of the table shows cases in which only a few

TABLE I

Experiment I, Effect of mouth washes as compared to control counts

\begin{tabular}{|c|c|c|c|c|c|c|c|}
\hline \multirow{2}{*}{ NAME } & \multirow{2}{*}{ MOUTH WASB USED } & \multirow{2}{*}{$\begin{array}{l}\text { NUNBER } \\
\text { OF } \\
\text { COUNTS }\end{array}$} & \multicolumn{3}{|c|}{$\begin{array}{l}\text { AVERAGE OY TOTAL NO. OF BAC- } \\
\text { TERARA REMOVED FBOK MOUTH* }\end{array}$} & \multicolumn{2}{|c|}{$\begin{array}{l}\text { VARLATTON FROM } \\
\text { INTTIAL COUNT }\end{array}$} \\
\hline & & & $\begin{array}{l}\text { Initial } \\
\text { count }\end{array}$ & $\begin{array}{l}3 \mathrm{hrs} . \\
\text { later }\end{array}$ & $\begin{array}{l}6 \mathrm{hrs} . \\
\text { later }\end{array}$ & $\begin{array}{l}3 \mathrm{hrs} . \\
\text { later }\end{array}$ & $\begin{array}{l}6 \text { hrs. } \\
\text { later }\end{array}$ \\
\hline \multirow{7}{*}{ M. C. } & & & & & & (per cent) & (per cent) \\
\hline & Azochloramid & 5 & 5,110 & 2,620 & 2,840 & -49 & -45 \\
\hline & Pepsodent & 7 & 4,120 & 1,690 & 1,800 & -59 & -57 \\
\hline & Lavoris & 5 & 4,630 & 2,560 & 3,260 & -45 & -30 \\
\hline & Listerine & 5 & 5,550 & 3,990 & 3,440 & -28 & -39 \\
\hline & Hexylresorcinol & 4 & 4,230 & 2,780 & 2,780 & -35 & -35 \\
\hline & Control & 10 & 4,360 & 3,770 & 3,740 & -14 & -15 \\
\hline \multirow{6}{*}{ M. K. } & Azochloramid & 3 & 5,610 & 2,560 & 3,070 & -55 & -46 \\
\hline & Pepsodent & 3 & 3,630 & 2,490 & 2,440 & -32 & -30 \\
\hline & Lavoris & 3 & 2,980 & 2,080 & 2,670 & -31 & -11 \\
\hline & Listerine & 2 & 2,760 & 2,100 & 3,120 & -24 & +12 \\
\hline & Hexylresorcinol & 2 & 3,060 & 2,620 & 3,000 & -15 & -2 \\
\hline & Control & 7 & 3,890 & 3,090 & 3,480 & -21 & -11 \\
\hline \multirow{6}{*}{ F. H. } & Azochloramid & 5 & 3,780 & 2,320 & 2,560 & -39 & -33 \\
\hline & Pepsodent & 6 & 4,660 & 2,500 & 2,790 & -47 & -41 \\
\hline & Lavoris & 5 & 6,280 & 2,720 & 5,620 & -57 & -11 \\
\hline & Listerine & 5 & 3,980 & 3,990 & 4,610 & 0 & +15 \\
\hline & Hexylresorcinol & 5 & 5,830 & 3,340 & 4,840 & -43 & -17 \\
\hline & Control & 10 & 4,340 & 4,110 & 5,420 & -6 & +24 \\
\hline \multirow{2}{*}{ F. } & Hexylresorcinol & 3 & 1,790 & 1,123 & 1,340 & -38 & -26 \\
\hline & Control & 4 & 2,350 & 2,400 & 2,400 & +2 & +2 \\
\hline \multirow{3}{*}{ o. z. } & Pepsodent & 3 & 8,900 & 7,290 & 4,800 & -19 & -48 \\
\hline & Listerine & 3 & 4,440 & 4,940 & 4,370 & +11 & -2 \\
\hline & Control & 3 & 7,320 & 9,030 & 8,890 & +23 & +21 \\
\hline \multirow{2}{*}{ C. K. } & Azochloramid & 3 & 6,530 & 3,910 & 3,670 & -41 & -44 \\
\hline & Control & 3 & 6,220 & 4,930 & 4,690 & -21 & -35 \\
\hline
\end{tabular}

* Expressed in millions.

antiseptics were tested on each individual. In the case of O. Z., Pepsodent 1:1 showed a decrease. The other cases do not show 
enough of a decrease to have any significance. It is interesting to see also that Listerine with O. Z., as in the case with F. H., shows an increase.

Experiment II-Table II. In the case of M. L. not one mouthwash showed a marked decrease. With M. C. the same is true. The most interesting thing about $\mathrm{M}$. $\mathrm{C}$. is the difference in counts between the controls of the two experiments. In the second experiment we have a decrease of 30 per cent at the end of 3 hours and 44 per cent at the end of 6 hours while in the first experiment, as pointed out in Table I,

TABLE II

Experiment II, Effect of mouth washes as compared to control counts

\begin{tabular}{|c|c|c|c|c|c|c|c|}
\hline \multirow{2}{*}{ NAMEE } & \multirow{2}{*}{ MOUTH WASE USED } & \multirow{2}{*}{$\begin{array}{l}\text { NOMBERR } \\
\text { OF } \\
\text { COUNTS }\end{array}$} & \multicolumn{3}{|c|}{$\begin{array}{l}\text { AVERAGE OF TOTAL NO. OF BAC- } \\
\text { TERIA REMOVED FROM YOUTH" }\end{array}$} & \multicolumn{2}{|c|}{$\begin{array}{l}\text { VARTATTON PROM } \\
\text { INITIALL COUNT }\end{array}$} \\
\hline & & & $\begin{array}{l}\text { Initial } \\
\text { count }\end{array}$ & $\begin{array}{l}3 \mathrm{hrs} \\
\text { later }\end{array}$ & $\begin{array}{l}6 \text { hrs. } \\
\text { later }\end{array}$ & $\begin{array}{l}3 \text { hrs. } \\
\text { later }\end{array}$ & $\begin{array}{l}6 \mathrm{hrs} \\
\text { later }\end{array}$ \\
\hline \multirow{6}{*}{ M. L. } & & & & & & (per cent) & (per centi) \\
\hline & Azochloramid & 3 & 4,080 & 3,070 & 3,020 & -25 & -26 \\
\hline & Zonite & 3 & 4,150 & 2,580 & 2,620 & -38 & -37 \\
\hline & Chlorazene & 3 & 5,070 & 2,810 & 2,580 & -45 & -49 \\
\hline & Pepsodent 1-3 & 3 & 5,310 & 2,830 & 3,040 & -47 & -43 \\
\hline & Control & 5 & 4,840 & 3,770 & 3,840 & -23 & -21 \\
\hline \multirow{5}{*}{ M. C. } & Azochloramid & 3 & 6,130 & 3,050 & 3,320 & -51 & -46 \\
\hline & Zonite & 3 & 6,450 & 3,120 & 3,510 & -48 & -46 \\
\hline & Chlorazene & 3 & 6,210 & 3,680 & 3,140 & -41 & -50 \\
\hline & Pepsodent 1-3 & 3 & 6,890 & 4,230 & 4,790 & -39 & -28 \\
\hline & Control & 5 & 7,030 & 4,940 & 3,950 & -30 & -44 \\
\hline
\end{tabular}

* Expressed as millions.

the decrease was only 14 per cent at 3 hours and 15 per cent at 6 hours. This is a good example of the difficulty in judging tests of this type.

\section{DISCUSSION}

The results of these experiments show much individual variation and reaction to the separate mouthwashes. The type of organism predominating in the mouth may play a part. The organisms in the mouth of $\mathbf{M}$. K. were predominately gram negative and here Azochloramid gave the best results. In M. C., Experiment I, where gram positive cocci predominated, both Pepsodent 1:1 and Azo- 
chloramid reduced the number of organisms materially but in Experiment II, where the oral flora had changed to one in which gram positive rods (B. acidophilus) predominated, no one of the antiseptics used decreased materially the control count which was much higher than in Experiment I.

While some of these antiseptics gave good results as far as reducing the oral flora was concerned, there are other reasons which would mitigate against their use. Pepsodent in a 1:1 dilution and Hexylresorcinol at the same dilution when held in the mouth for one minute caused a burning sensation. Hexylresorcinol at this concentration was only a mild antiseptic. Pepsodent at a 1:3 dilution did not give extremely satisfying results. Chlorozene and Zonite besides not giving marked reductions in the only two cases tested, have too unpleasant a taste to have much of a popular appeal. Azochloramid while not having an obnoxious taste was only fairly antiseptic.

In our opinion no definite conclusions can be drawn as to the antiseptic value of the mouthwashes tested because of the great variation in the same individual from time to time in both control and experimental tests. Count methods are not to be relied upon in testing mouthwashes.

It might be stated here that in the light of our present limited knowledge in oral bacteriology, we cannot assume that a mouthwash effective in reducing oral flora is advantageous in maintaining good oral health. We do not know but that by depressing certain harmless bacteria we may be actually lowering the resistance of the individual against disease producing forms. 